\begin{tabular}{lr}
\hline Jurnal Abdimas llmiah & JURNAL ABDIMAS ILMIAH CITRA BAKTI \\
Citra Bakti & Volume 2, Nomor 1, April 2021 \\
(JAICB) & ISSN 2721-9178 \\
\hline
\end{tabular}

\title{
PENGGUNAAN METODE COMMUNICATIVE LANGUAGE TEACHING PADA PELATIHAN KETERAMPILAN BERBICARA GURU SMA SINT LOUIS SEMARANG
}

\author{
Djoko Sri Bimo1), Maria Yustina Rensi Dartani ${ }^{2)}$, Binti Muflikah³) \\ ${ }^{1,2,3)}$ Program Studi Pendidikan Bahasa Inggris, ${ }^{1)}$ Universitas Terbuka UPBJJ Surakarta, ${ }^{2)}$ \\ Universitas PGRI Semarang, ${ }^{3}$ Universitas Terbuka UPBJJ Semarang \\ ${ }^{1)}$ djokosb@ecampus.ut.ac.id, ${ }^{2)}$ mariayustina68@gmail.com, ${ }^{3)}$ binti@ecampus.ut.ac.id
}

\section{Histori artikel}

Received:

15 Februari 2021

Accepted:

02 April 2021

Published:

19 April 2021

\begin{abstract}
Abstrak
Pengabdian ini diadakan dengan tujuan untuk mengajarkan bahasa Inggris speaking kepada guru-guru SMA Sint Louis Semarang. Pengabdian ini berbentuk pelatihan yang bertujuan untuk membekali para guru di SMA Sint Louis Semarang agar dapat memiliki keterampilan berbicara, berkomunikasi dalam bahasa Inggris dengan baik dan benar, dan pelatihan ini diperuntukkan bagi seluruh guru, baik guru bahasa Inggris maupun guru bidang studi lain. Metode pembelajaran yang digunakan dalam pelatihan ini adalah Communicative Language Teaching (CLT). Metode tersebut mendorong para peserta pelatihan untuk lebih mengembangkan kemampuan dirinya, memahami tentang bahasa Inggris dan cara berkomunikasi, sehingga pada individu terjadi perubahan sikap dan memiliki kecakapan dalam berbicara bahasa Inggris. Teknik yang digunakan dalam pelatihan ini yaitu teknik deskriptif dengan pendekatan kuantitatif. Sampel berjumlah 25 orang peserta, berasal dari latar belakang bidang ilmu yang berbeda. Pelatihan dilakukan selama 10 kali dengan durasi waktu selama 90 menit setiap sesinya. Hasil menunjukkan bahwa ada peningkatan kemampuan peserta dalam berkomunikasi menggunakan Bahasa Inggris. Peserta mampu menuangkan idenya dan mengungkapkannya dalam percakapan. Berdasarkan hasil analisis secara deskriptif juga diperoleh adanya peningkatan minat dan motivasi peserta. Peserta sudah mulai memiliki rasa percaya diri saat melakukan percakapan (conversation) dengan teman ataupun dengan tim abdimas.
\end{abstract}

Kata-kata Kunci: keterampilan berbicara, communicative language teaching 
Abstract. The community service was held with the aim of teaching English Speaking to Sint Louis Senior High School teachers in Semarang. This service was in the form of training that aimed at equipping teachers at SMA Sint Louis Semarang so they can have speaking skills, can communicate in English properly and correctly, and this training was intended for all teachers, both English teachers and teachers in other fields of study. The learning method used in this training was Communicative Language Teaching (CLT) training to further develop their skills, understand English and how to communicate so that individuals can change attitudes and have proficiency in speaking English. The technique used in this training was a descriptive technique with a quantitative approach. The sample consisted of 25 participants, coming from different scientific backgrounds. The training was carried out for 10 times with a duration of 90 minutes each session. The result showed that there was an increase in the participants' ability to communicate using English. Participants were able to express their ideas and express them in a conversation. Based on the results of the descriptive analysis, there was also an increase in participants' interest and motivation. Participants have started to have self-confidence when having conversations with friends or with team of community service.

Keywords: speaking skill, communicative language teaching method

\section{PENDAHULUAN}

Pada era globalisasi ini bahasa Inggris dipandang sebagai suatu kebutuhan. Bahasa Inggris menjadi hal utama yang perlu dikuasai oleh masyarakat Indonesia untuk mempengaruhi, berinteraksi, mengeksplorasi, menjelaskan, menumbuhkan dan memperkenalkan identitasnya kepada orang lain, agar dapat keluar dari keterbatasan informasi dan pergaulan. Sebagai masyarakat yang berkembang dan ingin maju, penting kiranya untuk berinteraksi dan bersosialisasi dengan para penduduk dunia, tidak cukup hanya sebatas di negara dimana kita tinggal. Juriana (2017) menyatakan bahwa penguasaan bahasa Inggris merupakan salah satu modal dasar untuk dapat berkompetisi dalam menghadapi era global terutama komunitas ASEAN.

Menurut Nurhasanah (2017), tidak bisa dipungkiri bahwa saat ini segala bentuk informasi banyak yang menggunakan bahasa Inggris, dan hal ini menuntut para guru untuk meng-upgrade dirinya untuk menyesuaikan perkembangan pengetahuan yang terjadi. Dia berpendapat bahwa upaya peningkatan kualitas pendidikan tidak akan berarti tanpa didukung guru yang profesional dan berkualitas. Lebih lanjut Nurhasanah menyatakan bahwa peningkataan kompetensi guru tersebut merupakan kebijakan strategis dalam rangka membenahi persoalan guru secara mendasar. Berdasarkan pada asumsi tersebut dapat disimpulkan bahwa dua hal untuk masuk ke ranah globalisasi adalah kecakapan komunikasi internasional dengan bahasa asing dan kemampuan berkomunikasi dengan teknologi informasi

Berbicara (speaking) adalah kemampuan seseorang dalam mengungkapkan atau mengekspresikan ide, pikiran yang ada dalam diri yang melibatkan orang lain dalam menyampaikan informasi tersebut dengan menggunakan kata-kata (Saddhono \& Slamet, 2014). Berbicara merupakan komunikasi secara lisan, maksudnya menyampaikan pemikiran dan perasaan secara lisan kepada lawan bicara. Melalui komunikasi tiap individu dapat 
saling bertukar pikiran dan perasaan (Rufaidah, 2015). Setyonegoro (2013) menambahkan bahwa berbicara adalah salah satu kemampuan berkomunikasi dengan orang lain melalui media bahasa.

Menurut Iskandarwassid (2011: 241) keterampilan berbicara pada hakikatnya merupakan keterampilan memproduksi arus sistem bunyi artikulasi untuk menyampaikan kehendak, kebutuhan perasaan, dan keinginan kepada orang lain. Faktor-faktor yang mempengaruhi keterampilan berbicara yaitu faktor kebahasaan dan nonkebahasaan. Indikator keterampilan berbicara meliputi ketepatan ucapan, pemilihan kata (diksi), sikap dan mimik, kenyaringan suara serta ekspresi lagu.

Menurut Rokhayani (2015) kemampuan berbicara dalam bahasa Inggris (speaking) adalah kemampuan untuk mengungkapkan dan menggunakan bahasa Inggris secara lisan dengan penggunaan kosa kata bahasa Inggris serta ide/gagasan yang tersampaikan dengan baik dan benar. Speaking English merupakan salah satu kecakapan yang harus dimiliki oleh seorang guru, namun karena beberapa alasan maka tidak semua guru bisa berkomunikasi menggunakan bahasa asing tersebut.

Selama ini kemampuan speaking English tersebut dirasa masih kurang oleh sebagian guru. Kurangnya kemampuan tersebut biasanya disebabkan oleh sulitnya mengungkapkan ide secara lisan (speaking), terbatasnya kosakata (vocabulary), terbatasnya melafalkan kata-kata (pronounciation), dan kurangnya keberanian untuk berbicara karena takut salah (unconfident).

Permasalahan yang dihadapi sebagian besar para guru termasuk guru di SMA Sint Louis Semarang adalah kemampuan berbicara/berkomunikasi menggunakan bahasa Inggris, baik kepada siswa maupun kepada tamu asing yang datang ke sekolah tersebut. Perbincangan dengan beberapa guru kelas dan Kepala SMA Sint Louis Semarang diperoleh penjelasan bahwa ternyata masih terdapat banyak kesulitan-kesulitan tentang proses pembelajaran bahasa Inggris, terutama yang menyangkut kemampuan berbicara (speaking).

Karena faktor-faktor yang disebutkan di atas dan untuk mengatasi permasalahan tersebut, maka pelatihan bahasa Inggris speaking untuk guru diadakan. Moekijat (dalam Kamil, 2010) mengatakan bahwa tujuan pelatihan yaitu untuk mengembangkan keahlian, untuk mengembangkan pengetahuan, untuk mengembangkan sikap.

Menurut Fitriati (2018), terdapat dua manfaat utama pelatihan bahasa Inggris, khususnya bahasa Inggris untuk tujuan pengajaran (Speaking for Instructional Purposes). Pertama, guru-guru akan memiliki kemampuan yang memadai untuk mengelola seluruh kegiatan kelas dalam bahasa Inggris. Para guru perlu memiliki ketrampilan berbicara yang khusus diperuntukkan untuk tujuan ini. Kedua, bahasa guru yang sering didengar anak selama kegiatan berlangsung dapat menjadi model bahasa interaksi yang diperlukan dalam kelas maupun di luar kelas. Guru adalah agen bahasa Inggris pertama dan terdekat yang 
dapat diakses siswa sehingga guru perlu menguasai bahasa lisan untuk konteks pengajaran bahasa.

Pengabdian kepada masyarakat yang berbentuk pelatihan ini tujuannya adalah untuk membekali para guru supaya bisa berkomunikasi dalam bahasa Inggris dengan benar, dan sebagai penunjang aktivitas keseharian guru dalam melaksanakan tugasnya sekaligus upaya meningkatkan kompetensi dan profesionalisme guru. Program ini diharapkan dapat memberikan manfaat bagi khalayak sasaran, yaitu: (1) peningkatan kemampuan penguasaan bahasa Inggris guru;(2) memotivasi guru untuk belajar bahasa Inggris,sehingga dapat meningkatkan kemampuan mereka dalam bidang bahasa Inggris;(3) hasil pelatihan ini juga dapat digunakan sebagai bahan pertimbangan untuk pengambil kebijakan yang terkait dengan peningkatan kualitas guru.

Hal tersebut sesuai dengan apa yang disampaikan oleh Hymes dalam Fachrurrozi dan Mahyuddin (2010) bahwa tujuan pengajaran bahasa adalah untuk mengembangkan kompetensi komunikatif, yaitu kemampuan menggunakan bahasa untuk berbagai tujuan dan dalam berbagai situasi dan kondisi.

Pengabdian masyarakat ini dilaksanakan di SMA Sint Louis yang beralamat di Jl Dr Wahidin No 110 Semarang dengan menggunakan metode CLT. Penggunaan metode pembelajaran tersebut diharapkan dapat memberikan lebih banyak kesempatan berbicara dalam bahasa Inggris kepada peserta pelatihan, dan juga dapat melibatkan peserta untuk berrmain peran/role play (berakting) sebagai suatu karakter dalam sebuah situasi. Dan setelah pelatihan selesai diharapkan para guru SMA Sint Louis Semarang memiliki kemampuan penguasaan Bahasa Inggris yang memadai, terutama dalam speaking skill yang dilatihkan. Kemampuan ini diharapkan akan menunjang dalam proses belajar mengajar di sekolah tersebut. Tujuan pengajaran bahasa adalah mengembangkan apa yang diebut oleh Hymes (dalam Fachrurrozi dan Mahyuddin, 2010, hlm. 86) sebagai kompetensi komunikatif, yaitu kemampuan menggunakan bahasa untuk berbagai tujuan dan dalam berbagai situasi dan kondisi.

Pendekatan CLT adalah suatu pembelajaran bahasa yang berprinsip pada komunikasi, dapat menimbulkan hubungan situasi sosial dalam kegiatan pembelajaran sehingga dapat meningkatkan keaktifan siswa dalam penggunaan bahasa secara lisan yang mengandung arti atau makna. (Sumantri, 2015: 92)

Larsen (2011), mengatakan bahwa communicative language teaching aims broadly to apply the theoretical perspective of the communicative approach by making communicative competence the goal of language teaching and by acknowledging the independents of language and communication. Jadi berdasarkan pendapat Larsen, dapat disimpulkan bahwa tujuan dari pengajaran bahasa komunikatif yaitu memberikan kebebasan kepada pengguna bahasa atau pelajar untuk menggunakan bahasa dalam berkomunikasi. 
Sebelumnya, pelatihan pembelajaran bahasa Inggris dengan menggunakan metode CLT ini dilakukan oleh Maduwu (2016). Maduwu menyatakan bahwa metode tersebut merupakan metode yang efektif dipakai dalam proses belajar mengajar bahasa Inggris, karena selain meningkatkan kemampuan peserta pelatihan untuk berkomunikasi, metode tersebut juga memotivasi peserta untuk mengembangkan ide/gagasan dalam berinteraksi menggunakan bahasa Inggris.

\section{METODE PELAKSANAAN}

Menurut Hatimah (2010:10), memberitahukan bahwa kedudukan metode dalam pembelajaran mempunyai ruang lingkup sebagai cara dalam: pemberi dorongan, yaitu cara yang digunakan sumber belajar dalam rangka memberikan dorongan kepada warga belajar untuk terus mau belajar. Dan untuk dapat menggunakan metode yang tepat maka ada beberapa faktor yang harus kita perhatikan, Menurut Ishak Abdulhak (2000), faktor yang harus diperhatikan yaitu faktor tujuan pembelajaran, faktor bahan belajar, faktor manusia, faktor waktu dan faktor sarana penunjang. Terlepas daripada itu semua, menurut Sugiyono (2013) secara umum metode merupakan suatu cara ilmiah untuk mendapatkan data dengan tujuan dan kegunaan tertentu.

Dalam kegiatan pelatihan pembelajaran Bahasa Inggris speaking ini metode yang digunakan adalah penggunaan metode CLT. Metode ini menekankan pada exposure yaitu suatu metode yang memberikan kesempatan lebih banyak berbicara (speaking) dibandingkan grammar, writing maupun reading. Littlewood dalam Febriyanti (2017) menyatakan bahwa CLT adalah metode yang berjalan bersamaan antara penguasaan struktur bahasa dan penguasaan komunikasi, karena dua hal tersebut tidak dapat dipisahkan dan saling berkaitan untuk menguasai sebuah bahasa khususnya bahasa Inggris. Lebih lanjut menurut Richards dan Rodgers dalam Febriyanti (2017) menjelaskan bahwa ada lima prinsip dalam menggunakan metode CLT yaitu: (1) pembelajar belajar bahasa adalah untuk berkomunikasi;(2) keontetikan dan kemaknaan komunikasi menjadi tujuan dari kegiatan yang ada didalam kelas;(3) kelancaran adalah dimensi yang penting di dalam berkomunikasi; (4) komunikasi mencakup integrasi dari empat keterampilan dalam pembelajaran bahasa.

Dalam pelatihan ini tim abdimas menggunakan teori Moss (2003) yaitu:

1. Conversation grids

Conversation grids akan dibagikan kepada peserta kemudian peserta tersebut dapat mempraktekkan isi dari conversation grids. Kegiatan ini dapat meningkatkan kemampuan berkomunikasi peserta

\section{Questionnaires}


Questionnaires bertujuan untuk mengetahui sejauh mana kemampuan peserta dalam memahami materi soal yang diberikan dan dapat melihat kemampuan peserta mengungkapkan pendapat mereka ketika mereka menjawab semua questionaires.

3. Games

Games merupakan kegiatan yang penting untuk membantu peserta dalam proses pelatihan pembelajaran.. Kegiatan ini bertujuan agar peserta tidak merasa bosan pada saat pelatihan..

4. Information gap activities

Aktivitas ini dapat melatih peserta supaya mampu berkomunikasi. Dalam aktivitas ini tidak semua peserta memperoleh informasi yang lengkap sehingga mereka harus saling berkomunikasi untuk bisa melengkapi informasi tersebut.

5. Problem-solving activities

Dalam aktivitas ini, peserta diberi sebuah masalah dan dibentuk kelompok agar dapat memecahkan masalah tersebut bersama-sama. Tujuan dari aktivitas ini agar peserta dapat meningkatkan kemampuan berbicaranya.

6. Discussion (diskusi) Diskusi merupakan sebuah kegiatan yang berisi dua orang atau lebih/berkelompok yang biasa dibentuk untuk berkomunikasi agar dapat memecahkan masalah dan menemukan jawaban dari masalah tersebut.

7. Role-plays (bermain peran) Dalam kegiatan ini, siswa diharuskan berperan sebagai tokoh yang sudah dipilih. Unsur peran dalam kegiatan ini selalu dihubungkan dengan tujuan penggunaan bahasa.

Pelatihan ini dilakukan selama $10 \times$ (setiap hari Sabtu) setelah jam pelajaran sekolah usai dengan jumlah peserta sebanyak 25 guru. Durasi pelatihan adalah 90 menit dengan rincian 1 jam belajar di dalam lab bahasa dan 30 menit praktik bahasa Inggris dengan konsep bermain peran/role playing.

Kegiatan pengabdian masyarakat ini dibuat dalam beberapa tahapan yang telah dirancang dengan baik. Tujuannya agar program ini diharapkan mampu berjalan sesuai dengan yang diharapkan. Tahapannya adalah sosialisasi, pelatihan, pendampingan dan evaluasi. Seperti yang dikatakan oleh Susanti \& Rukiati (2017), bahwa tahapan ini dipilih karena berdasarkan hasil pengamatan yang dilakukan, tahapan inilah yang seyogyanya paling cocok untuk diterapkan.

Materi pelatihan diambil dari berbagai sumber yaitu dari buku Chambridge Speaking, dan Speaking Naturally. Sumber dari internet (youtube) juga disertakan. Adapun materi pelatihan adalah: Greeting, Introducing Oneself and Others, Making an Appointment, Making a Request, Inquiring about Health, Asking for Direction, Asking for Information, Sympathy, At the Restaurant. Asking for A drink. And About Shopping. 
Untuk lebih jelasnya materi yang diajarkan kepada peserta disajikan pada Tabel 1 berikut.

Tabel 1. Materi Pelatihan

\begin{tabular}{|c|c|c|c|c|c|c|c|c|c|c|}
\hline \multirow{2}{*}{ Mate } & \multicolumn{10}{|c|}{ Pertemuan Ke } \\
\hline & 1 & 2 & 3 & 4 & 5 & 6 & 7 & 8 & 9 & 1( \\
\hline \multicolumn{11}{|l|}{ Greeting } \\
\hline \multicolumn{11}{|c|}{ Introducing oneself and others } \\
\hline \multicolumn{11}{|c|}{ Making an appointment } \\
\hline \multicolumn{11}{|c|}{ Making a request } \\
\hline \multicolumn{11}{|c|}{ Inquiring about health } \\
\hline \multicolumn{11}{|c|}{ Asking for direction } \\
\hline \multicolumn{11}{|c|}{ Asking for information } \\
\hline \multicolumn{11}{|c|}{ Sympathy } \\
\hline \multicolumn{11}{|l|}{ At the restaurant } \\
\hline Shopping & & & & & & & & & & \\
\hline
\end{tabular}

\section{Indikator Keberhasilan}

Kriteria keberhasilan dari kegiatan pelatihan ini dapat dilihat dari indikator keberhasilan proses dan indikator keberhasilan hasil belajar/pemahaman. Indikator keberhasilan proses yang ditetapkan dalam pelatihan ini adalah jika peserta pelatihan mampu mencapai $75 \%$. Indikator proses pembelajaran dalam pelatihan ini akan dilihat dari prosentase keberhasilan tindakan yang didasarkan pada data skor yang diperoleh dari hasil observasi peserta pelatihan. Dari segi hasil pembelajaran dikatakan berhasil apabila terjadi perubahan tingkah laku yang positif pada diri peserta pelatihan seluruhnya atau sekurangkurangnya $75 \%$. Atau dengan kata lain indicator hasil belajar dari pelatihan ini adalah jika $75 \%$ dari siswa telah mencapai nilai $\geq 75$.

Hal tersebut seperti yang disampaikan oleh Mulyasa (2005), bahwa kriteria keberhasilan pelatihan pembelajaran dapat dilihat dari ketuntasan pencapaian peserta terhadap materi mencapai $75 \%$ dan peserta didik yang mendapat 75 setidaknya $75 \%$ dari jumlah seluruh peserta didik. Secara lengkap kriteria tingkat penguasaan disajikan pada table 2 berikut :

Tabel 2. Tingkat Penguasaan

\begin{tabular}{cccc}
\hline Tingkat Penguasaan & Nilai Huruf & Bobot & Predikat \\
\hline $90 \% \leq \mathrm{NR} \leq 100 \%$ & $\mathrm{~A}$ & 4 & Sangat baik \\
$80 \% \leq \mathrm{NR}<90 \%$ & $\mathrm{~B}$ & 3 & Baik \\
$70 \% \leq \mathrm{NR}<70 \%$ & $\mathrm{C}$ & 2 & Cukup \\
$60 \% \leq \mathrm{NR}<70 \%$ & $\mathrm{D}$ & 1 & Kurang \\
$0 \% \leq \mathrm{NR}<60 \%$ & $\mathrm{E}$ & 0 & Sangat kurang \\
\hline
\end{tabular}

\section{HASIL DAN PEMBAHASAN}

Hasil

Pertemuan pertama adalah agenda pretes yang bertujuan untuk mengukur kemampuan peserta, khususnya yang berkaitan dengan soal-soal materi bahasa Inggris conversation dan tes dasar speaking. Hasil dari pretes dijadikan sebagai pembanding tingkat keberhasilan tim dalam memberi pelatihan kepada peserta. Selain itu, hasil tersebut juga 
digunakan untuk melihat peningkatan pemahaman peserta dalam memahami kalimat dalam bahasa Inggris. Dengan demikian, tes-tes selanjutnya, postes (pertemuan terakhir) dijadikan sebagai evaluasi oleh tim abdimas, yaitu dengan membandingkan hasil pretes dengan postes. Perbandingan tersebut dilakukan untuk melihat adanya peningkatan hasil keterampilan berbicara peserta.

Pada tahap awal pelatihan peserta diperkenalkan materi-materi pelatihan, dimana materi tersebut dikemas dalam sebuah handout dan CD. Handout berisi text script, sedangkan CD berisi materi audio visual untuk mendukung pelatihan tersebut. Tahapantahapan dalam pelatihan terbagi menjadi 2 bagian yaitu pelatihan dan evaluasi. Dalam tahap pelatihan, tim abdimas memberikan/ mempresentasikan materi yang sudah ada dalam handout dengan disertai penayangan video/ audio visual interaktif yang berisi materi. Subtitle/teks dalam video memudahkan peserta untuk melatih pronunciation mereka, sehingga mereka memahami apa yang native speaker sampaikan. Pada tahap ini pula peserta berlatih untuk melakukan dialog tentang topik pilihannya masing-masing bersama dengan partnernya, mereka mempraktekkannya di depan kelas dengan membawa transkrip dan juga tanpa transkrip. Peserta diperbolehkan melakukan improvisasi atas percakapan yang telah mereka buat. Dalam tahap evaluasi, penilaian dilakukan oleh tim abdimas. Dari data yang terkumpul menunjukkan bahwa hasil pretest (tes awal) peserta pelatihan adalah 1120, dan hasil postest-nya adalah 1872. Peningkatan kemampuan para peserta disajikan pada Tabel 3.

Tabel 3. Perpandingan Perolehan Hasil Pretest dan Posttest Hasil Pretest Hasil Posttest

\begin{tabular}{|c|c|c|}
\hline$\Sigma$ & $=$ & 1120,00 \\
\hline $\mathrm{n}_{1}$ & $=$ & 25 \\
\hline$\overline{x_{1}}$ & $=$ & 44,80 \\
\hline$s_{1}{ }^{2}$ & $=$ & 86,6667 \\
\hline $\mathrm{S}_{1}$ & $=$ & 9,309 \\
\hline
\end{tabular}

\begin{tabular}{|c|c|c|}
\hline$\Sigma$ & $=$ & 1872,00 \\
\hline $\mathrm{n}_{1}$ & $=$ & 25 \\
\hline$\overline{x_{1}}$ & $=$ & 74,88 \\
\hline $\mathrm{s}_{1}{ }^{2}$ & $=$ & 40,6933 \\
\hline$s_{1}$ & $=$ & 6,379 \\
\hline
\end{tabular}

Data hasil peningkatan kemampuan para peserta pelatihan yang berdasarkan dari pretes dan postes digambarkan dalam bentuk diagram grafik disajikan pada Gambar 1.

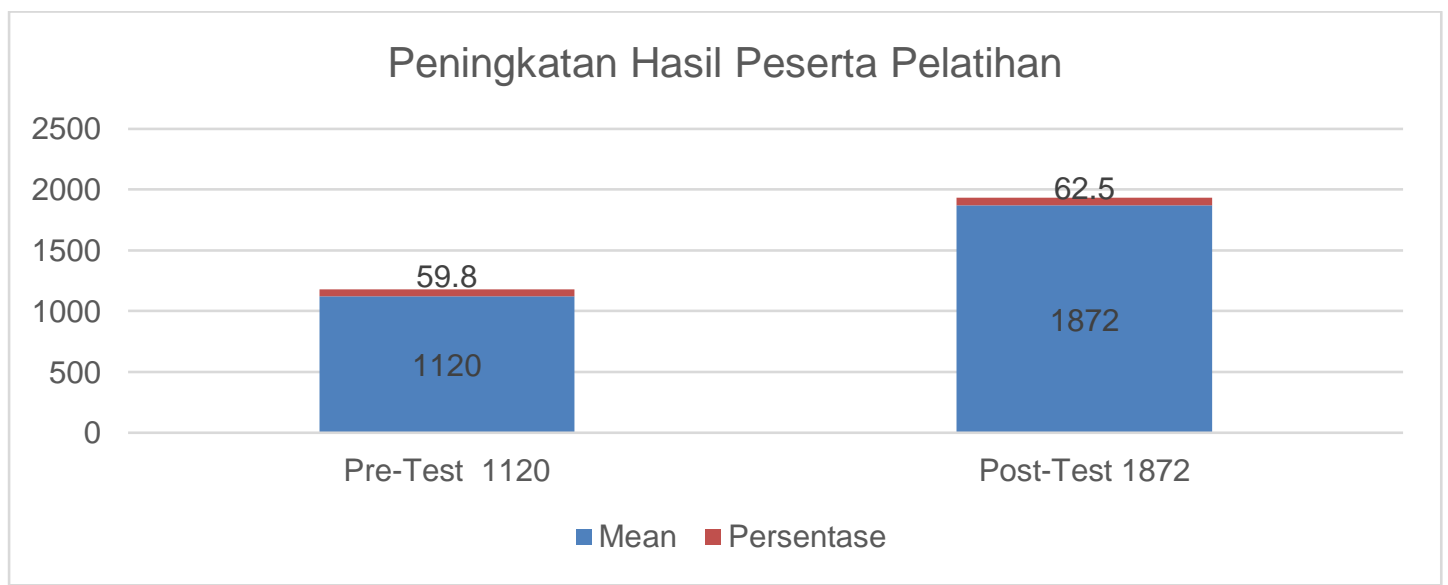

Gambar 1. Grafik Hasil Pretes dan Postes Peserta Pelatihan 


\section{Pembahasan}

Hasil evaluasi awal menunjukkan bahwa keterampilan berbicara para peserta pelatihan speaking tergolong masih rendah. Mereka belum mampu berbicara dengan lancar, dan dalam mengungkapkan sesuatu masih sering ada jeda, bahkan dalam berbicara terkesan berbelit-belit dan membingungkan. Hal itu dikarenakan kurangnya pengetahuan pada kosakata (vocabulary), tentang bagaimana pelafalan kata yang tepat (pronunciation) dan kurangnya pengetahuan tata bahasa (grammar). Sebagian besar peserta kurang memahami betul materi speaking tersebut, dikarenakan peserta berasal dari latar belakang program studi yang berbeda. Sikap canggung, khawatir, malu-malu terlihat dalam tes tersebut, sehingga bisa dikatakan bahwa peserta belum memiliki skill tentang speaking. Perasaan takut salah dalam mengucapkan kalimat sangat telihat sekali. Namun yang menarik dalam tes awal tersebut adalah sikap antusias mereka saat diperlihatkan dialog dari video/audio visual yang ditayangkan lewat LCD. Para peserta dengan seksama memperhatikan dan sesekali menirukan apa yang native speaker katakan.

Dari Gambar 1 bisa dilihat bahwa hasil pretes peserta pelatihan adalah 1120. Angka tersebut tergolong masih rendah karena hanya mencapai 59,8 \% saja. Namun setelah diberikan pelatihan dengan menggunakan metode CLT maka terlihat adanya perubahan hasil peserta, dimana postesnya adalah 1872 atau 62,5 \%. Dari data tersebut dapat disimpulkan bahwa ada peningkatan pemahaman dari peserta pelatihan bahasa Inggris speaking sebesar $27 \%$.

Dari hasil analisis secara deskriptif juga diperoleh peningkatan minat dan motivasi peserta disamping peningkatan kemampuan speaking peserta. Peserta sudah mulai memiliki rasa percaya diri saat melakukan percakapan (conversation) dengan teman ataupun dengan tim abdimas. Dalam lembar kuesioner peserta juga mengungkapkan perasaan senang melakukan percakapan yang didahului dengan penayangan video interaktif sebagai model. Metode pelatihan speaking dengan menggunakan metode CLT memudahkan para peserta menciptakan ide kreatif untuk melakukan speaking

Melalui penerapan metode CLT terhadap kemampuan berbicara bahasa Inggris, para guru dapat lebih mengeksplorasi kemampuan berinteraksi antara satu dengan lainnya. Dalam hal ini, para guru lebih memahami ketepatan makna percakapan yang sesuai dengan konteks dan fungsi bahasa dalam komunikasi. Pada penerapannya, metode pengajaran ini memberikan keleluasaan kepada para guru untuk dapat serta terlibat aktif secara bersama mengeksplorasi kemampuan berbicara bahasa Inggris sehingga motivasi para guru dapat meningkat secara signifikan. Hal ini dapat terlihat dari peningkatan interaksi sesama guru dalam melakukan percakapan bahasa Inggris.

Penelitian sebelumnya yang dilakukan oleh Widagdo (2017), dalam penelitiannya yang berjudul " Implementasi model pembelajaran CLT untuk meningkatkan kemampuan 
berbicara aktif bahasa Inggris berbasis nilai-nilai karakter " menyatakan bahwa penerapan model CLT terbukti dapat meningkatkan kemampuan berbicara aktif (active speaking) dalam perkuliahan bahasa Inggris, khususnya bagi mahasiswa PGSD UNNES. Hal ini karena implementasi atau penerapan model CLT memiliki kelebihan dalam meningkatkan berbicara aktif (active speaking) diantaranya yaitu dapat meningkatkan motivasi diri (self motivation) dan kepercayaan diri (self confidence). Peningkatan aspek motivasi diri (self motivation) dan kepercayaan diri (self confidence) dapat menyebabkan peningkatan peran aktif mahasiswa dalam aspek motorik yaitu mempresentasikan kemampuan motivasi diri (self motivation) dan kepercayaan diri (self confidence) di depan kelas secara individu. Hal tersebut menuntut mahasiswa untuk dapat berfikir dan bertindak secara optimal.

Penelitian yang dilakukan oleh Lestari (2017) menunjukkan bahwa pembelajaran keterampilan berbicara dengan menggunakan pendekatan Communication Language Teaching (CLT) dan strategi Numbered Heads Together (NHT) yang dilaksanakan secara berkala dapat meningkatkan keterampilan berbicara siswa kelas V SD Negeri Ngabeyan 3 tahun 2016/2017. Peningkatan tersebut ditunjukkan dengan nilai rata-rata kelas yang telah diperoleh. Pada saat sebelum dilaksanakan tindakan, nilai rata-rata yang diperoleh yaitu, 69,6. Setelah dilaksanakan tindakan pada siklus I nilai rata-rata kelas 72,15 . Pada siklus II nilai rata-rata kelas semakin meningkat yaitu 81,06 . Selain dari rata-rata nilai kelas, pencapaian nilai KKM juga meningkat, yaitu pada pratindakan pencapaian KKM sebesar $40 \%$, pada siklus I pencapaian nilai KKM sebesar 55\% dan siklus II pencapaian KKM semakin meningkat yaitu $85 \%$. Hal ini berarti keterampilan berbicara siswa semakin meningkat dengan menggunakan pendekatan CLT dan NHT.

\section{KESIMPULAN}

Berdasarkan pada data yang diperoleh, maka dapat disimpulkan bahwa pelatihan pembelajaran bahasa Inggris speaking dengan menggunakan metode CLT berhasil dalam dua aspek yakni: mampu meningkatkan kemampuan speaking peserta, yang meliputi peningkatan pengejaan dan ke alamiahan percakapan, serta mampu meningkatkan minat dan motivasi peserta pelatihan untuk melakukan speaking.

Selanjutnya, keberhasilan kegiatan ini dilihat dari indikator keberhasilan program peserta pelatihan, yaitu adanya kenaikan skor yang didapatkan oleh peserta pelatihan dari pretes dan postes, dan selain itu peserta bisa berkomunikasi dalam bahasa Inggris dengan benar. Peserta pelatihan sangat merasakan manfaat dengan ditandai oleh adanya frekuensi dalam menerapkan percakapan dengan sesama peserta maupun dengan tamu atau wisatawan yang berkunjung di sekolah tersebut. 


\section{DAFTAR PUSTAKA}

Febriyanti, H.A. (2017). Penggunaan metode communicative language teaching dalam pengajaran bahasa Inggris pada guru tutor di bimbingan belajar. Faktor Jurnal IImiah Kependidikan, 4(3), 319-328.

Fitriati Wuli Sri dan Farida Noor Alief. (2018). Peningkatan kompetensi guru dalam speaking English for instructional purposes untuk pengajaran bilingual di SD Islam Al Azhar 29 BSB Semarang. Jurnal Rekayasa,16(2).

Hatimah, I, dkk. (2010). Strategi dan metode pembelajaran. Universitas Terbuka

Iskandarwassid. (2011). Strategi pembelajaran bahasa. Remaja Rosdakarya.

Juriana. (2017). Pentingnya penggunaan bahasa Inggris dalam komunikasi dakwah pada era global. Jurnal Dakwah Dan Pengembangan Sosial Kemanusiaan, 8(2).

Larsen-Freeman, Diane dan Anderson, Marti. (2011). Techniques and Principles in language teaching. Oxford

Maduwu, Byslina. (2016). Pentingnya pembelajaran bahasa Inggris di sekolah. Jurnal Warta, 50

Mulyasa. (2005). Kurikulum berbasis kompetensi. PT Remaja Rosdakarya

Kamil. M. (2010). Model pendidikan dan pelatihan (konsep dan aplikasi). Alfabeta

Lestari Fitri. (2017). Peningkatan keterampilan berbicara melalui pendekatan communication language teaching (CLT) dan strategi NHT pada pembelajaran bahasa Indonesia kelas V SDN Ngabeyan 3 Tahun 2016/2017. Skripsi. Universitas Muhammadiyah Surakarta].

Moss, D., \& Ross-Feldman, L. (2003). Second language acquisition in adults: From research to practice. $\mathrm{http}: / / \mathrm{www}$.cal.org/CAELA/esl_resources/digests/SLA.html.

Nurhasanah, Santi. (2017). Pelatihan peningkatan kompetensi berbahasa Inggris guru dalam pembelajaran bilingual di SDIT Bilingual Fithrah Insani Kab Bandung Barat. Jurnal Empowerement, 6(1).

Rokhayani Atik dan Cahya Nur Dwi Agung. (2015). Peningkatan keterampilan berbicara (speaking) mahasiswa melalui teknik English debate. Refleksi Edukatika Jurnal IImiah Kependidikan, 5(1).

Rufaidah, D. (2015). Model two stay two stray (TSTS) dalam diskusi pada pembelajaran bahasa Indonesia, 1(2).

Saddhono, K., \& Slamet, Y. (2014). Pembelajaran keterampilan berbahasa Indonesia: Teori dan Aplikasi. Graha IImu.

Sugiyono. (2013). Metode penelitian pendidikan (pendekatan kuantitatif, kualitatif, dan R\&D). CV ALFABETA

Sumantri, Mohamad Syarif. (2015). Strategi pembelajaran teori dan praktik di tingkat pendidikan dasar. PT Raja Grafindo Persada

Susanti, N., \& Rukiati, E. (2017). Pelatihan bahasa inggris bagi karang taruna di desa wisata lombok kulon bondowoso. [Seminar Nasional Hasil Pengabdian Kepada Masyarakat 2017. 251-256.

Setyonegoro, Agus. (2013). Hakikat, alasan, dan tujuan berbicara. Jurnal Pena Vol 3(1), 2089-3973

Widagdo Arif. (2017). Implementasi model pembelajaran CLT untuk meningkatkan kemampuan berbicara aktif bahasa Inggris berbasis nilai-nilai karakter. Jurnal Magistra, 9(2). 